Jurnal Abdimas Berdaya : Jurnal Pembelajaran, Pemberdayaan dan Pengabdian Masyarakat

Volume 4 Nomor 01 Tahun 2021

P-ISSN: $2685-1563$

e-ISSN: 2720 - 9768

\title{
Peningkatan Keterampilan Siswa MTs Melalui Pelatihan Pembuatan Hidroponik
}

\section{Improving MTs Student Skills through of Training Hydroponic}

\author{
Muhammad Farid Nasrulloh ${ }^{1}$, Ino Angga Putra ${ }^{2}$, Fitri Umardiyah ${ }^{3}$, \\ Muhammad Badrut Tamam ${ }^{4}$ \\ ${ }^{1234}$ Universitas KH. A. Wahab Hasbullah \\ e-mail: ${ }^{1}$ faridnasrulloh@unwaha.ac.id, ${ }^{2}$ inoanggaputra@unwaha.ac.id, \\ 3fitriumardiyah@unwaha.ac.id, ${ }^{4}$ Badrut.tamam5855@gmail.com
}

\begin{abstract}
Abstrak: Kegiatan pengabdian masyarakat ini dilaksanakan pelatihan membuat hidroponik sederhana dengan memanfaatkan botol air mineral. Kegiatan ini bertujuan meningkatkan semangat belajar, rasa ingin tahu, kemampuan keterampilan peserta didik serta menjaga lingkungan sekitar dari sampah. Pengabdian ini dilaksanakan di MTs Al_Hikmah Bandarkedungmulyo. Metode pendekatan dalam pelaksanaan kegiatan pengabdian masyarakat ini meliputi metode ceramah, diskusi, dan pelatihan. Metode ceramah dan diskusi dilaksanakan pada saat pengenalan materi. Hasil kegiatan pengabdian masyarakat dapat disimpulkan hal-hal sebagai berikut. (1) Memberikan wawasan tambahan dan pengetahuan serta keterampilan peserta didik di MTs AlHikmah Kecamatan Bandarkedungmulya dalam membuat hidroponik. (2) Meningkatkan kemampuan keterampilan, rasa ingin tahu dan semangat belajar peserta didik di MTs Al-Hikmah. (3) Membantu guru dalam mengaktifkan interasksi siswa dengan siswa dan menjaga lingkungan sekitar dari sampah.
\end{abstract}

Kata Kunci: Keterampilan, Pelatihan Hidroponik, Botol Air Mineral.

Abstract: Community service activity was carried out by training on making simple hydroponics using mineral water bottles. This activity aims to increase the enthusiasm for learning, curiosity, skill skills of students and protect the environment from rubbish. This service was carried out at MTs Al_Hikmah Bandarkbuildingmulyo. The approach method in the implementation of community service activities includes lectures, discussions and training methods. The lecture and discussion method was carried out at the time of introducing the material. The results of community service activities can be concluded as follows. (1) Provide additional insight and knowledge and skills of students at MTs Al-Hikmah, Bandarkbuildingmulya District in making hydroponics. (2) Improve the skills, curiosity and enthusiasm for learning of students at MTs Al-Hikmah. (3) Assisting teachers in activating student interaction with students and protecting the environment from rubbish.

Keywords: Skills, Hidroponics Training, Mineral Water Bottles.

\section{A. Pendahuluan}

Guru-guru di MTs Al-Hikmah Kecamatan Bandarkedungmulya Kabupaten Jombang mengalami banyak kendala dan hambatan terutama dalam penerapan kurikulum 2013. Pembelajaran kurikulum 2013 menuntut agar pembelajaran menjadi 
lebih aktif dan mengarah pada student center. Sedangkan hasil pengamatan di MTs AlHikmah Desa Pucangsimo peserta didik memiliki semangat dan rasa ingin tahu yang rendah. Mitra kegiatan pengabdian masyarakat adalah MTs Al-Hikmah. Lembaga pendidikan ini dipilih karena lokasinya yang dekat dengan tempat tim pelaksana dengan jarak kurang lebih $300 \mathrm{~m}$ dan salah satu sekolah yang masih melakukan pembelajaran tatap muka selama pandemi.

Fasilitas di sekolah tersebut juga masih sangat terbatas sehingga pembelajaran kurang begitu menarik dan cenderung membosankan. Beberapa hal yang dijumpai dilapangan antara lain: (1) Kurangnya fasilitas yang memadai, (2) Kurangnya kesadaran untuk memanfaatkan sampah terutama bekas air meniral. Berdasarkan pejabaran diatas, kegiatan pengabdian masyarakat dilaksanakan pelatihan membuat hidroponik sederhana dengan memanfaatkan botol air mineral. Kegiatan ini diharapkan dapat meningkatkan semangat belajar, rasa ingin tahu, kemampuan keterampilan peserta didik serta menjaga lingkungan sekitar dari sampah.

Hidroponik adalah lahan budidaya pertanian tanpa menggunakan media tanah, sehingga hidroponik merupakan aktivitas pertanian yang dijalankan dengan menggunakan air sebagai medium untuk menggantikan tanah. Sehingga sistem bercocok tanam secara hidroponik dapat memanfaatkan lahan yang sempit. Pertanian dengan menggunakan sistem hidroponik memang tidak memerlukan lahan yang luas dalam pelaksanaannya, tetapi dalam bisnis pertanian hidroponik hanya layak dipertimbangkan mengingat hanya dapat dilakukan dipekarangan rumah, atap rumah maupun lahan lainnya (Roidah, 2015)

Hidroponik merupakan salah satu system pertanian masa depan karena dapat diusahakan diberbagai tempat baik didesa di kota, dilahan terbuka atau diatas apartemen sekalipun. Luas tanah yang sempit, kondisi tanah kritis, hama dan penyakit yang tak terkendali, keterbatasan jumlah air irigasi, musim tidak menentu, dan mutu yang tidak seragam bias ditanggulangi dengan sistem hidroponik. Hidroponik dapat diusahakan sepanjang tahun tanpa mengenal musim. Oleh karena itu, harga jual panennya tidak khawatir akan jatuh. Pemeliharaan tanaman hidroponik pun lebih mudah karena tempat budidayanya relatif bersih, media tanamnya steril, tanaman terlindung dari terpaan hujan, serangan hama dan penyakit relatif kecil, serta tanaman lebih sehat dan produktivitas lebih tinggi (Wibowo \& S, 2013).

Salah satu jenis sayur yang mudah dibudidayakan adalah tanaman sawi. Sayuran berdaun hijau ini termasuk tanaman yang tahan terhadap air hujan, dan dapat dipanen sepanjang tahun karena tidak tergantung dengan musim. Masa panen pun terbilang cukup pendek, karena setelah 40 hari ditanam sawi sudah data dipanen. Disamping kemudahan dalam proses budidaya, sayur sawi juga banyak dijadikan sebagai peluang bisnis karena peminatnya yang cukup banyak. Permintaan pasarnya juga cukup stabil, 
sehingga resiko kerugian sangan kecil. Hidroponik merupakan usaha yang sangat menguntungkan apabila dipratikkan dan dilakukan dengan keseriusan (Madusari dkk., 2020)

Berdasarkan permasalahan yang dihadapi oleh mitra, maka kegaiatan pengabdian masyarakat melalui pelatihan membuat hidroponik sederhana dengan memanfaatkan botol air mineral memiliki tujuan sebagai berikut:

1. Meningkatkan kemampuan keterampilan, semangat dan rasa ingin tahu peserta didik dalam mengikuti kegiatan pembelajaran.

2. Meningkatkan kemampuan dan pemahaman peserta didik dalam membuat hidroponik sederhana melalui kegiatan pelatihan.

Pelaksanaan kegiatan pengabdian masyarakat ini diharapkan dapat memberikan hasil yang terbaik untuk masyarakat sasaran yang dikenai program. Permasalahan pertama adalah peserta didik dengan rasa ingin tahu yang rendah, kurangnya tenaga pendidik dan fasilitas yang kurang memadai. Solusi yang diberikan adalah melalui pelatihan pembuatan hidroponik sederhana dengan memanfaatkan botol air mineral kepada peserta didik sehingga luaran yang diperoleh yaitu sebagai berikut.

1. Tingkat semangat, rasa ingin tahu serta kemampuan keterampilan peserta didik dalam pembelajaran jadi lebih meningkat.

2. Dengan menyarankan salah satu teman untuk menjadi tenaga pendidik khususnya di bidang ilmu sains.

Target luaran yang dihasilkan pada kegiatan ini pada lembaga MTs Al-hikmah diharapkan dapat memberikan pengaruh yang positif terhadap kualitas pembelajaran dan kemampuan belajar peserta didik. Selain itu, diharapkan dapat dapat memotivasi guru untuk bisa melakukan pembelajaran dengan lebih menarik sehingga tingkat rasa ingin tahu, semangat dan kemampuan keterampilan peserta didik lebih meningkat serta menjaga lingkungan sekitar dari sampah. Target luaran tersebut dapat dilihat secara spesifik pada tabel 1 .

Tabel 1. Target Luaran

\begin{tabular}{lllllr}
\hline \multicolumn{2}{c}{ Permasalahan } & \multicolumn{2}{c}{ Tujuan } & \multicolumn{2}{c}{ Tolak Ukur } \\
\hline Semangat dan rasa ingin & Meningkatkan kemapuan & 1. Peserta & didik dapat \\
tahu peserta didik yang & keterampilan, semangat dan & membuat & hidroponik \\
rendah dalam kegiatan & rasa ingin tahu peserta didik & sederhana & dengan \\
pembelajaran & & melalui program pelatihan & memanfaatkan botol air \\
& & membuat hidroponik & mineral. &
\end{tabular}

$\begin{array}{lr}2 . & \text { Terwujudnya } \\ \text { pembelajaran } & \text { yang } \\ \text { berkualitas } & \text { dalam } \\ \text { mendukung } & \text { peningkatan } \\ \text { kemampuan peserta didik. }\end{array}$




\begin{tabular}{|c|c|c|}
\hline Permasalahan & Tujuan & Tolak Ukur \\
\hline Kurangnya tenaga pendidik & $\begin{array}{l}\text { Membantu sekolah dalam } \\
\text { hal SDM }\end{array}$ & $\begin{array}{l}\text { Tim pengabdian masyarakat } \\
\text { bersedia membantu tenaga } \\
\text { pendidik di sekolah. }\end{array}$ \\
\hline
\end{tabular}

\section{B. Metode}

Khalayak sasaran pada kegiatan pelatihan membuat hidroponik dengan memanfaatkan botol air mineral ini adalah peserta didik MTs Al-hikmah Desa Pucangsimo Kecamatan Bandarkedungmulya dengan jumlah 29 anak. Pada kegiatan ini narasumber berasal dari tim pelaksana pengabdian masyarakat yang telah dipelajari.

Metode pendekatan dalam pelaksanaan kegiatan pengabdian masyarakat ini meliputi metode ceramah, diskusi, dan pelatihan. Metode ceramah dan diskusi dilaksanakan pada saat pengenalan materi. Metode pelatihan dilaksanakan ketika selesai menerima materi dan saat membuat hidroponik sederhana. Melalui kegiatan pelatihan ini diharapkan dapat menyelesaikan permasalahan yang dihadapi oleh pihak mitra. Berikut tabel 2 menampilkan solusi sebagai penyelesaian rumusan masalah yang ada.

Tabel 2 Rancangan Solusi Permasalahan

\begin{tabular}{cll}
\hline No & \multicolumn{1}{c}{ Permasalahan } & \multicolumn{1}{c}{ Solusi } \\
\hline 1 & Rendahnya semangat belajar dan rasa ingin tahu & 1. Presentasi \\
& peserta didik & 2. Teori \\
& & 3. Praktik \\
\hline 2 & Kurangnya tenaga pendidik & $\begin{array}{l}\text { Tim bersedia membantu } \\
\text { tenaga pendidik }\end{array}$ \\
\hline
\end{tabular}

Metode ceramah, diskusi dan pelatihan yang digunakan akan dilaksanakan selama dua jam dengan struktur program pelaksanaan kegiatan pengabdian ini sebagai berikut:

Tabel 3 Struktur Program Pelatihan Membuat Hidroponik Sederhana dengan Memanfaatkan Botol Air Mineral

\begin{tabular}{lllcc}
\hline No & \multicolumn{1}{c}{ Materi } & \multicolumn{1}{c}{ Kegiatan } & $\begin{array}{c}\text { Jumlah } \\
\text { Jam }\end{array}$ & $\begin{array}{c}\text { Jumlah } \\
\text { Peserta }\end{array}$ \\
\hline 1 & Pengenalan materi & $\begin{array}{l}\text { 1. Presentasi } \\
\text { 2. Focus Group Discusion }\end{array}$ & 1 & \multirow{2}{*}{29} \\
\cline { 1 - 3 } 2 & Praktik & $\begin{array}{l}\text { 1. Teori } \\
\text { 2. Praktik }\end{array}$ & 1 & \\
\hline \multicolumn{2}{l}{ Total } & & 2 & 29 \\
\hline
\end{tabular}

\section{Hasil dan Pembahasan}

Pelaksanaan kegiatan pengabdian masyarakat ini didukung oleh beberapa pihak salah satunya adalah Lembaga Penelitian dan Pengabdian Masyarakat (LPPM) 
UNWAHA yang bekerja sama dalam hal SDM dengan pihak Fakultas dan Program Studi sesuai dengan kegiatan yang akan dilaksanakan. Kegiatan ini akan mencapai keberhasilan dan kelancaran karena adanya kerjasama dengan mitra dimana sumber permasalahan diperoleh dari pihak mitra tersebut. Pelaksanaan ini bersifat partisipatori, dimana tim pengusul mitra secara bersama-sama dan proaktif untuk terlibat dalam setiap kegiatan.

Pelaksanaan kegiatan pengabdian masyarakat dilakukan pada bulan Oktober 2020. Kegiatan dilaksanakan dalam bentuk sosialisasi, pelatihan dan pendampingan melalui satu kali pertemuan atau tatap muka. Pelaksanaan ini dilakukan di Madrasah Tsanawiyah Al-Hikmah Desa Pucangsimo Kecamatan Bandarkedungmulya. Berikut rancangan tahapan pelaksanaan kegiatan disajikan pada tabel 4.

Tabel 4 Rancangan Pelaksanaan Kegiatan Pengabdian

\begin{tabular}{clcc}
\hline No & \multicolumn{1}{c}{ Jenis Kegiatan } & Bukti Dokumen & Waktu Pelaksanaan \\
\hline 1 & $\begin{array}{l}\text { Koordinasi awal atau observasi ke } \\
\text { lokasi pengabdian dan izin } \\
\text { pengabdian }\end{array}$ & $\begin{array}{l}\text { Surat kesediaan } \\
\text { kerjasama }\end{array}$ & 15 Oktober 2020 \\
\hline 2 & $\begin{array}{l}\text { Persiapan dan penyusunan materi } \\
\text { pelatihan membuat hidroponik }\end{array}$ & $\begin{array}{l}\text { Alat dan bahan } \\
\text { Foto kegiatan }\end{array}$ & 23 Oktober 2020 \\
\hline 3 & $\begin{array}{l}\text { Pelatihan Membuat Hidroponik } \\
\text { Sederhan dengan Memanfaatkan } \\
\text { Botol Air Mineral }\end{array}$ & $\begin{array}{l}\text { Daftar hadir dan } \\
\text { foto kegiatan }\end{array}$ & 24 Oktober 2020 \\
& \multicolumn{3}{c}{} \\
\hline 4 & Publikasi di Jurnal Seminar dan & Draft Artikel, & 17 November 2020 \\
& Media cetak Elektronik & $\begin{array}{l}\text { Materi, Presentasi } \\
\text { dan Foto Kegiatan }\end{array}$ & \\
\hline 5 & Pelaporan & Laporan & 17 November 2020 \\
\hline
\end{tabular}

Rancangan evaluasi dari uraian pada tahapan pelaksanaan kegiatan pengabdian masyarakat ini dilaksanakan menggunakan beberapa instrumen penilaian pada kegiatan yang dilaksanakan. Rancangan evaluasi pelaksanaan program secara lebih rinci akan disajikan pada tabel 5.

Tabel 5 Rancangan Evaluasi Pelaksanaan Kegiatan Pengabdian

\begin{tabular}{clcc}
\hline No & \multicolumn{1}{c}{ Jenis Kegiatan } & Bukti Dokumen & Waktu Pelaksanaan \\
\hline 1 & $\begin{array}{l}\text { Koordinasi awal atau observasi ke } \\
\text { lokasi pengabdian dan izin } \\
\text { pengabdian }\end{array}$ & Foto kegiatan & 15 Oktober 2020 \\
\hline 2 & $\begin{array}{l}\text { Persiapan dan penyusunan materi } \\
\text { pelatihan membuat hidroponik }\end{array}$ & $\begin{array}{c}\text { Alat dan bahan } \\
\text { Foto kegiatan dan } \\
\end{array}$ & $\begin{array}{c}\text { File materi } \\
\text { pelatihan }\end{array}$ \\
\hline
\end{tabular}




\begin{tabular}{clcc}
\hline No & \multicolumn{1}{c}{ Jenis Kegiatan } & Bukti Dokumen & Waktu Pelaksanaan \\
\hline 3 & Pelatihan Membuat Hidroponik & Daftar hadir, & 24 Oktober 2020 \\
& Sederhan dengan Memanfaatkan & Angket dan foto & \\
& Botol Air Mineral & kegiatan
\end{tabular}

\begin{tabular}{clcc}
\hline 4 & $\begin{array}{l}\text { Publikasi di Jurnal, Seminar dan } \\
\text { Media Cetak/Elektronik }\end{array}$ & $\begin{array}{c}\text { Draft artikel, } \\
\text { Materi Presentasi } \\
\text { Foto Kegiatan }\end{array}$ & 17 November 2020 \\
\hline 5 & Pelaporan & Laporan & 17 November 2020 \\
\hline
\end{tabular}

Rencana jangka panjang dari kegiatan pengabdian masyarakat ini melalui kegiatan pelatihan untuk peningkatan rasa ingin tahu kemampuan keterampilan serta semangat belajar para peserta didik MTs Al-Hikmah dalam pelatihan membuat hidroponik sederhana dengan memanfaatkan botol air mineral. Kegiatan ini dilakukan terus menerus dengan menyesuaikan perkembangan zaman dan kemajuan IPTEKS melalui kegiatan pelatihan. Keberlanjutan program ini perlu dikomunikasikan dan dikoordinasikan dengan pihak yang berada di lembaga UPTD di wilayah Kabupaten Jombang sehingga ke depannya dilaksanakan secara lebih luas lagi.

Tindaklanjut dari kegiatan ini akan dilakukan melalui kegiatan pembuatan hidroponik sederhana dengan lebih banyak yang disesuaikan dengan kemajuan IPTEKS dan desain yang lebih menarik. Melalui kegiatan ini diharapkan peserta didik menjadi lebih semangat dalam belajar dan berpikir kreatif. Selain itu produk dari hasil pelatihan yang telah dibuat oleh peserta didik dapat digunakan untuk memperindah rumah, sekolah dan lingkungan. Selain itu, Hasil dari pelatihan ini diharapkan para remaja mampu berkreasi dan kreatif dalam rangka ketahanan pangan yang akan menjadi tolok ukur dalam tingkat kesejahteraan masyarakat (Permadi dkk., 2020).

Kegiatan pengabdian masyarakat ini telah dilakukan pada bulan Oktober 2020. Kegiatan ini terdiri dari beberapa tahapan yang sudah dilakukan sebagai berikut. Koordinasi dengan Mitra, Awal program kegiatan pengabdian masyarakat ini dilaksanakan dengan melakukan koordinasi awal melalui izin pelaksanaan yang dilakukan dengan Kepala Madrasah Tsanawiyah Al-Hikmah Bapak Muhammad Nadlir, M.Pd beserta guru.. Hasil koordinasi dengan pihak mitra mengizinkan melakukan kegiatan sesuai dengan jadwal yang telah ditentukan. Setelah perjanjian selesai, selanjutnya dilakukan dengan koordinasi lanjutan dengan peserta didik terkait dengan program pelatihan membuat hidroponik sederhana dengan memanfaatkan botol air mineral. Hal ini dilakukan dengan menyebarkan kuesioner kepada peserta didik yang mengikuti program pelatihan tersebut. 
Penyusunan materi pada kegiatan ini disusun oleh tim pelaksana dengan melakukan kajian pustaka dari berbagai referensi terkait dengan hidroponik. Tahap penyusunan materi ini dimulai pada awal pelaksanaan dan digunakan untuk sosialisasi dengan peserta didik. Selain itu, dilaksanakan perancangan pembuatan hidroponik sederhana dengan memanfaatkan botol air mineral. Sosialisasi pembuatan hidroponik sederhana dengan memanfaatkan botol air mineral melalui kegiatan pelatihan. Sosialisasi ini dilaksanakan untuk memberikan wawasan dan pengetahuan kepada peserta didik. Kegiatan ini diikuti oleh 29 peserta didik yang bertempat di MTs AlHikmah Kecamatan Bandarkedungmulya Kabupaten Jombang pada tanggal 24 Oktober 2020. Narasumber dalam kegiatan ini adalah tim pelaksana kegiatan pengabdian masyarakat.

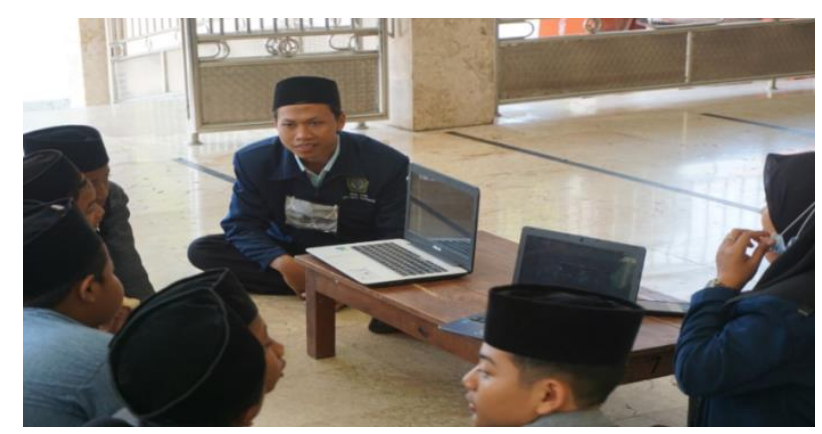

Gambar 1. Sosialisasi kegiatan pelatihan hidroponik

Kegiatan selanjutnya adanya kegiatan diskusi dan tanya jawab peserta pelatihan yang dikemas melalui Focus Group Discusion. Hasil dari kegiatan tersebut menunjukkan bahwa beberapa peserta didik masih belum tahu mengenai hidroponik dan mengalami kebingungan ketika membuat hidroponik sederhana dengan memanfaatkan botol air mineral.

Kegiatan pelatihan ini juga dilaksanakan penyebaran angket pemahaman materi sebelum dan setelah kegiatan pelatihan. Hasil pengisian angket tersebut menunjukkan bahwa peserta didik mengalami peningkatan pemahaman materi hidroponik dan bagaimana cara membuat hidroponik sederhana dengan memanfaatkan botol air mineral. Pelatihan membuat hidroponik sederhana dengan memanfaatkan botol air mineral merupakan tahap selanjutnya setelah sosialisasi tentang materi hidroponik pada tanggal 24 Oktober 2020. Hidroponik merupakan solusi alternatif menanam pada lahan yang sempit sehingga menanam sayuran dan buah-buahan semakin mudah (Purwasih, 2019).

Kegiatan ini mencakup: (a) mempersiapkan alat dan bahan untuk membuat hidroponik sederhana, (b) membagi kelompok, (c) tim pelaksana mencontohkan bagaimana cara membuat hidroponik sederhana menggunakan alat dan bahan yang telah dipersiapkan, (d) peserta didik membuat hidroponik sederhana. Kegiatan ini dilakukan 
selama 1 kali tatap muka. Kegiatan ini membantu peserta didik untuk memanfaatkan botol air mineral di lingkungan sekitar menjadi sesuatu yang bermanfaat sekaligus menjaga lingkungan sekitar dari sampah. Selain itu, kegiatan ini juga dapat meningkatkan semangat dan kemampuan psikomotor peserta didik. Hal ini ditunjukkan dengan antusias dan keaktifan peserta didik dalam membuat hidroponik sederhana selama kegiatan berjalan.

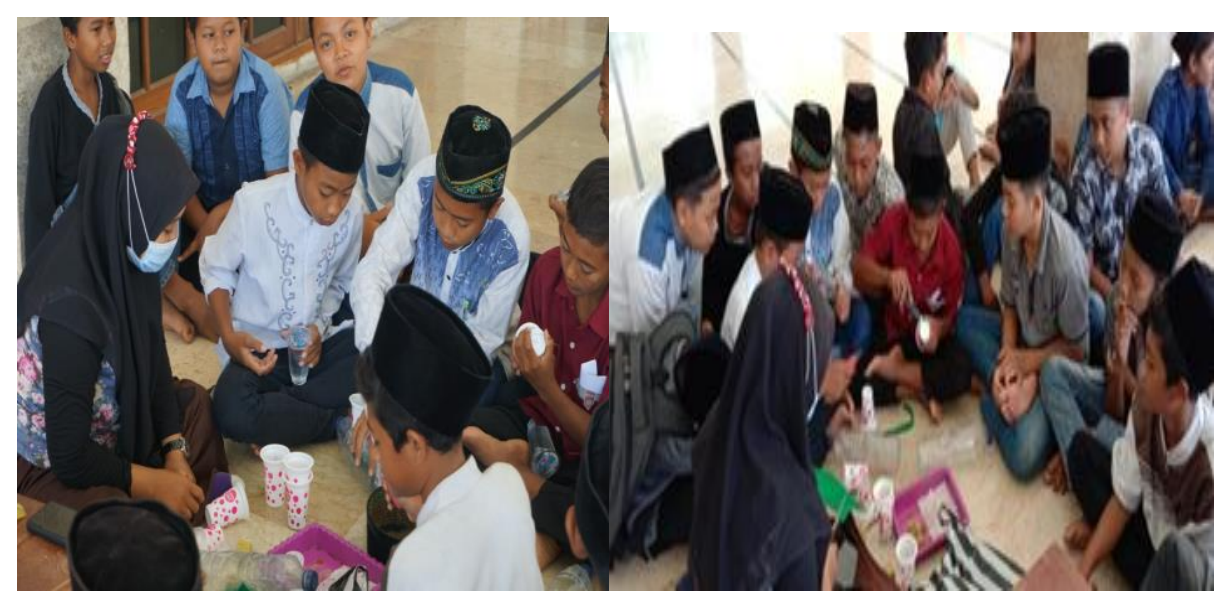

Gambar 2. Antusiasme Peserta

Kegiatan pelatihan ini juga dilakukan penyebaran angket respon kepuasan peserta pelatihan. Hasil respon kepuasan kegiatan pelatihan menujukkan bahwa peserta pelatihan menilai kegiatan ini sangat bermanfaat dan menyenangkan, Selain itu kegiatan ini juga memberikan pengalaman langsung kepada peserta didik dalam membuat hidroponik sederhana dengan menfaatkan botol air mineral. Proses belajar memungkinkan menjadikan adanya interaksi antara peserta didik dengan sumber belajar di sekitarnya (Nasrulloh dkk., 2020). Hasil penilaian keterampilan peserta pelatihan menunjukkan bahwa 70\% sebagian besar peserta pelatihan memiliki keterampilan yang baik ketika membuat hidroponik sederhana. Sedangkan sebanyak 30\% peserta pelatihan dalam kategori dengan keterampilan kurang baik dimana hal tersebut dipengaruhi oleh ketidakpahaman dengan materi yang telah disampaikan.

Tabel 6. Hasil Penilaian Keterampilan Peserta

\begin{tabular}{clc}
\hline No & \multicolumn{1}{c}{ Uraian } & Skor rata-rata \\
\hline 1 & $\begin{array}{l}\text { Kemampuan memahami petunjuk pembuatan hidroponik } \\
\text { sederhana }\end{array}$ & 3,7 \\
\hline 2 & Kemampuan membuat hidroponik sederhana & 3,4 \\
\hline
\end{tabular}




\begin{tabular}{llc}
\hline No & Uraian & Skor rata-rata \\
\hline 3 & Kemampuan mengetahui manfaat hidroponik sederhana & 3,6 \\
& & 3,2 \\
\hline 4 & Kemampuan menjelaskan teori tentang hidroponik & \\
\hline Keterangan: & \\
70\% Peserta pelatihan memiliki keterampilan yang baik & \\
$30 \%$ & Peserta pelatihan memiliki keterampilam kurang baik & \\
\hline
\end{tabular}

\section{Simpulan}

Berdasarkan hasil kegiatan pengabdian masyarakat dapat disimpulkan hal-hal sebagai berikut. (1) Memberikan wawasan tambahan dan pengetahuan serta keterampilan peserta didik di MTs Al-Hikmah Kecamatan Bandarkedungmulya dalam membuat hidroponik. (2) Meningkatkan kemampuan keterampilan, rasa ingin tahu dan semangat belajar peserta didik di MTs Al-Hikmah. (3) Membantu guru dalam mengaktifkan interasksi siswa dengan siswa dan menjaga lingkungan sekitar dari sampah. Kegiatan pengabdian masyarakat ini memang sudah dilaksanakan sampai dengan tahap pembuatan mandiri hidroponik sederhana di MTs Al-Hikmah. Perlu diperhatikan bahwa kegiatan ini tidak berhenti hanya sampai kegiatan pengabdian dilaksanakan. Namun, kegiatan ini juga dapat diimplementasikan dengan masyarakat sekitar atau lembaga pendidikan yang lain. Hal yang perlu dilakukan adalah mengembangkan atau melestarikan hidroponik ini sebagai hal yang dapat memberikan manfaat yang positif dilingkungan sekitar. 


\section{Daftar Rujukan}

Madusari, S., Astutik, D., \& Sutopo, A. (2020). INISIASI TEKNOLOGI HIDROPONIK GUNA MEWUJUDKAN KETAHANAN PANGAN MASYARAKAT PESANTREN. Jurnal Pengabdian Masyarakat Teknik, 2(2), 45-52. https://doi.org/10.24853/jpmt.2.2.41-48

Nasrulloh, M. F., Nasoih, A. K., Satiti, W. S., \& Afifa, S. K. (2020). Mengatasi Problematika Pembelajaran Bahasa Arab melalui Pelatihan dan Permainan Bahasa Arab. JUMAT PENDIDIKAN: JURNAL PENGABDIAN MASYARAKAT, 1(1), 28-35.

Permadi, H., Yuliana, Y., Wardhani, I. S., Nastiti, N. D., \& Prasetyo, S. M. (2020). WORKSHOP PEMBUATAN HIDROPONIK WICK SYSTEM SEBAGAI UPAYA KETAHANAN PANGAN MASYARAKAT DESA KASRI. Jurnal Graha Pengabdian, 2(3), 202-211.

Purwasih, R. (2019). Pemanfaatan Lahan Pekarangan untuk Budi Daya Sayuran Secara Hidroponik di Kecamatan Sungailiat, Kabupaten Bangka, Provinsi Kepulauan Bangka Belitung. Agrokreatif: Jurnal Ilmiah Pengabdian Kepada Masyarakat, 5(3), 195-201.

Roidah, I. S. (2015). PEMANFAATAN LAHAN DENGAN MENGGUNAKAN SISTEM HIDROPONIK. Jurnal BONOROWO, 1(2), 43-49-49.

Wibowo, S., \& S, A. A. (2013). Aplikasi Hidroponik NFT pada Budidaya Pakcoy (Brassica rapa chinensis). Jurnal Penelitian Pertanian Terapan, 13(3), Article 3. https://doi.org/10.25181/jppt.v13i3.180 